\title{
Empirical Research on the Roles of Financial Services Clustering to Regional Economic Growth
}

\author{
Hongyue Li \\ Nanfang College \\ Sun Yat-sen University \\ Guangzhou, China
}

\begin{abstract}
A sound relation is considered existing between financial services clustering and regional economic growth, which are promoted mutually and correlated. There are no deep empirical researches found and conducted upon the relations between the two in China, besides, a good many specific problems need to be faced. This article conducts a case study on ten cities with characteristics of financial services clustering in the country, through the tests of mixed OLS, random effect model and fixed effect model, the result of the fixed effect model is thought acceptable: the financial services clustering is a great push to the regional economic growth.
\end{abstract}

Keywords-financial services clustering; regional economic growth; promotion

\section{INTRODUCTION}

It is widely accepted by a good many scholars that a sound relation is considered existing between financial services clustering and regional economic growth, which are promoted mutually and correlated. After the economic development approaches a certain level in an area, financial resources and financial institutions will get together to the place in order to achieve the pursuit of higher economic benefits and richer profits so that the financial services clustering will come into being, based on which, abundant financial resources, perfect financial institutions and healthy financial market may offer enough funds and first-rate financial services for the local economic development, efficiently driving the economic development, and further form an "economic development--financial clustering---economic development" positive cycle. A great number of scholars at home and abroad have conducted deep theoretical analysis and empirical tests on the relations between financial services clustering and regional economic growth.

There are no deep empirical researches found and conducted upon the relations between financial services clustering and regional economic growth, besides, a good many specific problems need to be faced, mainly including: (1)Previous researches which were short in sample spacing and time span made it inadequate in persuasion; (2) Previous data selected were mostly cross-section data and time-series data, in the opinion of the author, panel data will be better for empirical tests and make the conclusion more believable; (3)Previous empirical approaches adopted were mostly linear regression, however, with the rapid development in econometrics, the use of new metric methods have greatly increased the empirical tests quality and reliability, and this article tries to verify the relation between financial services clustering and regional economic growth via new methods applicable. (4) Previous indices selected were mostly traditional monetary stock indices (MO/GDP), only analyzing the influence of bank loans and deposits to the economic growth, the article will adopt more rational indices to verify the relations between financial services clustering and regional economic growth.

\section{MODELS AND METHODS}

In the past years, the metric methods have been improved gradually, and the panel data become much easier to access to, so the panel data model has been widely used, whose formula is given as follows:

$$
Y_{i t}=\alpha_{i t}+\beta_{i t} x_{i t}+u_{i t}
$$$$
i=1,2,3 \cdots \cdots \cdot n ; t=1,2,3 \cdots \cdots \cdot T
$$

The formula reflects the dynamic relations of $\mathrm{k}$ economic indices on $\mathrm{N}$ sample(s) at $\mathrm{T}$ time point(s), $\mathrm{N}$ here refers to number of cross, $T$ refers to observation period of per section, $\mathrm{k}$ refers to number of explanatory variable, ait refers to constant, $\beta$ it refers to coefficient vector of $\mathrm{k}^{*} 1$ dimension corresponding to explanatory variable xit, $\mu$ it refers to random error, all are independent for each other.

We adopt a static panel data module, where the explanatory variables contain no lagged items of the explained variables. Generally there are three static models created with panel data, namely random effect model, fixed effect model and Ordinary Least Square (abbreviated as OLS). The premise for the application of fixed effect model is assuming that the orientations and effects of all research achievements are basically the same, applicable for independent researches with no or few differences; generally the OLS is used for assessment. The random effect model takes the original regression coefficient as a random variable, and the general assumption is the data from normal distribution, generally it adopts the least squares dummy variable (LSDV) for estimation. If the coefficients of a part of a model are random but others are fixed, it is called a mixed model. 


\section{SAMPLES AND INDICES}

Research data available show, there are ten cities with characteristics of financial services clustering, including Beijing, Shanghai, Shenzhen, Guangzhou, Tianjin, Suzhou, Chongqing, Hangzhou, Nanjing and Chengdu, whose financial coverage spreads to ten provinces and cities as Shanghai, Zhejiang and Jiangsu in the Yangtze River delta economic circle; Guangdong of Pearl River Delta; Beijing, Tianjin, Shandong and Hebei surrounding Bohai economic circle as well as Chongqing and Sichuan in the middle west region. Therefore, the ten provinces and cities are taken as samples for the research, according to the data of 1999-2014, the STATA software is used to verify the roles of financial services clustering to regional economic growth. The economic growth is of great complexity, so four control variables are introduced to the model, reflecting governmental roles, infrastructure, human capital and foreign investment utilization respectively, as shown in "Table I".

TABLE I. INDICES AND MEANING FOR THE EMPIRICAL RESEARCH

\begin{tabular}{|c|c|c|c|}
\hline Type & $\begin{array}{c}\text { Item\& } \\
\text { Acronym } \\
\end{array}$ & Formula & Economic Meaning \\
\hline $\begin{array}{l}\text { Explained } \\
\text { variable }\end{array}$ & $\begin{array}{l}\text { Per capita } \\
\text { Gross } \\
\text { Domestic } \\
\text { Product } \\
\text { (PGDP) }\end{array}$ & $\begin{array}{l}\text { Ratio between } \\
\text { provincial per } \\
\text { capita GDP and } \\
\text { national per capita } \\
\text { GDP }\end{array}$ & $\begin{array}{l}\text { Weigh the economic } \\
\text { growth speed and } \\
\text { development level, } \\
\text { positively related. }\end{array}$ \\
\hline $\begin{array}{l}\text { Explanatory } \\
\text { variable }\end{array}$ & $\begin{array}{l}\text { Proportion of } \\
\text { financial } \\
\text { output value } \\
\text { (EJR) }\end{array}$ & $\begin{array}{l}\text { Proportion of } \\
\text { provincial financial } \\
\text { output value in that } \\
\text { of the nation }\end{array}$ & $\begin{array}{lr}\text { Weigh } & \text { financial } \\
\text { services } & \text { clustering } \\
\text { degree, } & \text { positively } \\
\text { related. } & \\
\end{array}$ \\
\hline \multirow{4}{*}{$\begin{array}{l}\text { Control } \\
\text { variable }\end{array}$} & $\begin{array}{l}\text { Proportion of } \\
\text { fiscal } \\
\text { expenditure } \\
\text { (Gov) }\end{array}$ & $\begin{array}{l}\text { Proportion of } \\
\text { provincial } \\
\text { government budget } \\
\text { expenditure in that } \\
\text { of the nation }\end{array}$ & $\begin{array}{l}\text { Weigh the roles of } \\
\text { government in the } \\
\text { economic } \\
\text { development, } \\
\text { positively related. }\end{array}$ \\
\hline & $\begin{array}{l}\text { Proportion of } \\
\text { fixed assets } \\
\text { investment } \\
\text { (Inv) }\end{array}$ & $\begin{array}{l}\text { Proportion of local } \\
\text { fixed assets } \\
\text { investment in that } \\
\text { of the nation }\end{array}$ & $\begin{array}{l}\text { Weigh the } \\
\text { infrastructure level, } \\
\text { positively related. }\end{array}$ \\
\hline & $\begin{array}{l}\text { Proportion of } \\
\text { students of } \\
\text { colleges and } \\
\text { universities } \\
(\mathrm{Lab}) \\
\end{array}$ & $\begin{array}{l}\text { Proportion of } \\
\text { students of } \\
\text { provincial colleges } \\
\text { and universities in } \\
\text { that of the nation }\end{array}$ & $\begin{array}{l}\text { Weigh the human } \\
\text { capital level, } \\
\text { positively related. }\end{array}$ \\
\hline & $\begin{array}{l}\text { Proportion of } \\
\text { foreign } \\
\text { investment } \\
\text { (For) }\end{array}$ & $\begin{array}{l}\text { Proportion of } \\
\text { provincial foreign } \\
\text { investment in that } \\
\text { of the nation }\end{array}$ & $\begin{array}{l}\text { Weigh the } \\
\text { contribution of } \\
\text { foreign resources to } \\
\text { economic growth, } \\
\text { positively related. }\end{array}$ \\
\hline
\end{tabular}

Suppose control variables are added, the financial services clustering and the regional economic growth are positively related, namely the development of financial services clustering will be a great push to the local economic growth.

\section{EMPIRICAL TEST}

Before the empirical analysis, here are descriptive statistics of variables, as shown in "Table II"
TABLE II.

DESCRIPTIVE STATISTICS OF VARIABLES

\begin{tabular}{|l|l|l|l|l|l|l|}
\hline $\begin{array}{c}\text { Descriptive } \\
\text { Statistics }\end{array}$ & PGDP & EJR & GOV & INV & LAB & FOR \\
\hline Mean value & 1.7679 & 7.04 & 3.639 & 5.47 & 4.6332 & 9.9814 \\
& 25 & 3121 & 944 & 7467 & 69 & 09 \\
\hline Max value & 3.8239 & 14. & 7.843 & 11.8 & 8.6913 & 33.738 \\
& 04 & $\begin{array}{l}7540 \\
994\end{array}$ & 7504 & 4 & 53 \\
\hline Min value & 0.6147 & 1.43 & 1.232 & 1.68 & 1.8929 & 0.5817 \\
001 & 124 & 1664 & 27 & 778 \\
\hline $\begin{array}{l}\text { Standard } \\
\text { deviation }\end{array}$ & 0.888 & 3.74 & 1.463 & 2.81 & 1.8565 & 8.4741 \\
\hline $\begin{array}{l}\text { Observation } \\
\text { count }\end{array}$ & 120 & 3792 & 619 & 068 & 13 & \\
\hline
\end{tabular}

Through mixed OLS regression, panel data-based fixed effect model and random effect model are used to verify the influence of financial services clustering to regional economic growth, as shown in "Table III".

TABLE III. EMPIRICAL TEST RESUlt OF FINANCIAL SERVICES CLUSTERING TO REGIONAL ECONOMIC GROWTH

\begin{tabular}{|c|c|c|c|}
\hline $\begin{array}{l}\text { Variable and } \\
\text { Constant }\end{array}$ & Mixed OLS & $\begin{array}{c}\text { Fixed Effect } \\
\text { Model }\end{array}$ & $\begin{array}{c}\text { Random } \\
\text { Effect } \\
\text { Model }\end{array}$ \\
\hline $\begin{array}{l}\text { Proportion of financial } \\
\text { output value(EJR) }\end{array}$ & $\begin{array}{l}0.229 * * * \\
(6.30)\end{array}$ & $\begin{array}{l}0.0627 * * * \\
(6.86)\end{array}$ & $\begin{array}{l}0.0653 * * * \\
(6.67)\end{array}$ \\
\hline $\begin{array}{l}\text { Proportion of fiscal } \\
\text { expenditure (Gov) }\end{array}$ & $\begin{array}{l}-0.335^{*} \\
(-2.59)\end{array}$ & $\begin{array}{l}0.0908 * * \\
(2.89)\end{array}$ & $\begin{array}{l}0.0801 * \\
(2.38)\end{array}$ \\
\hline $\begin{array}{l}\text { Proportion of fixed } \\
\text { assets investment (Inv) }\end{array}$ & $\begin{array}{l}0.0177 \\
(0.31)\end{array}$ & $\begin{array}{l}0.0767 * * * \\
(5.74)\end{array}$ & $\begin{array}{l}0.0762 * * * \\
(5.26)\end{array}$ \\
\hline $\begin{array}{l}\text { Proportion of students } \\
\text { of colleges and } \\
\text { universities (Lab) }\end{array}$ & $\begin{array}{l}-0.200 \\
(-2.06)\end{array}$ & $\begin{array}{l}0.0618 * \\
(2.55)\end{array}$ & $\begin{array}{l}0.0451 \\
(1.74)\end{array}$ \\
\hline $\begin{array}{l}\text { Proportion of foreign } \\
\text { investment (For) }\end{array}$ & $\begin{array}{l}0.0213 \\
(0.87)\end{array}$ & $\begin{array}{l}-0.0102 * \\
(-2.41)\end{array}$ & $\begin{array}{l}-0.0103^{*} \\
(-2.25)\end{array}$ \\
\hline Constant (cons) & $\begin{array}{l}1.988^{*} \\
(2.85)\end{array}$ & $\begin{array}{l}0.392 * * \\
(2.76)\end{array}$ & $\begin{array}{l}0.494 * \\
(2.06)\end{array}$ \\
\hline
\end{tabular}
level test of $5 \%$; ** refers to passing a significance level test of $1 \%$; *** refers to passing a significance level test of $0.1 \%$

\section{RESULT ANALYSIS}

From the "Table III", it can be seen:

(1) Through whether the mixed regression equation or the fixed effect model or the random effect mode, it can be seen that the proportion of financial output value has a positive promotion to the proportion of per capita GDP, passing $t$ test with the significance level of $0.1 \%$. In the mixed regression equation, the fixed effect model and the random effect model, when a unit is increased for the financial services clustering, the per capital GDP will increase by $0.229,0.0627$ and 0.0653 respectively, which proves our assumption, namely the financial services clustering may raise the liquidity of financial resources and its utilization efficiency through sharing financial information, resources, service and infrastructures, promoting the sustainable, steady and rapid development of economy, so as to achieve the positive cycle "economic development-financial clustering-economic development".

(2) The control variables show, in the mixed OLS regression equation, the proportion of fiscal expenditure has an obvious inhibition to the economic growth, but in the fixed 
effect model and the random effect model, it brings a push to the economic growth, being efficient at the significance levels of $1 \%$ and $5 \%$ respectively; the proportion of fixed assets investment has a push to the economic growth, though it is not distinct in the mixed OLS regression equation, yet it, in the fixed effect model and the random effect model, is efficient with the significance level of $0.1 \%$; the proportion of students of colleges and universities brings little drive to the economic growth, which passes the significance test of $5 \%$ only in the fixed effect model; the proportion of foreign investment brings an inhibition to economic growth, passing $t$ tests with the significance level of $5 \%$ in both the fixed effect model and the random effect model.

(3) After comparing the three empirical results, we can find that the conclusion of the fixed effect model is basically agreeing on that of the random effect model, similar in influential orientation and strength; compared to the results of random effect and fixed effect, the influences of many variables (as such as proportion of fixed assets investment, proportion of students of colleges and universities, proportion of foreign investment) of the mixed OLS regression result fail to pass the significance tests, besides, their influential orientations are reverse (i.e. in the result of mixed OLS, the proportion of fiscal expenditure has an inhibition to economic growth, which is inconsistent with other results and also illogical). As for the advantages and disadvantages of the mixed OLS, the random effect model and the fixed effect model, it can be judged through Wald test, B-P test and Hausman, as shown in "Table IV".

TABLE IV. MIXED OLS, FIXED EFFECT OR RANDOM EFFECT

\begin{tabular}{|l|l|l|l|}
\hline \multicolumn{1}{|c|}{$\begin{array}{c}\text { Original } \\
\text { Assumption }\end{array}$} & \multicolumn{1}{|c|}{$\begin{array}{c}\text { Testing } \\
\text { Method }\end{array}$} & \multicolumn{1}{|c|}{ Test Results } & Conclusion \\
\hline $\begin{array}{l}\text { The mixed } \\
\text { regression is } \\
\text { acceptable }\end{array}$ & Wald test & $\begin{array}{l}\mathrm{F}(9,105)=231.54 \\
\text { Prob }>\mathrm{F}=0.0000\end{array}$ & $\begin{array}{l}\text { Refuse original } \\
\text { assumption, and } \\
\text { select the fixed } \\
\text { effect }\end{array}$ \\
\hline $\begin{array}{l}\text { The variance of } \\
\text { individual effect } \\
\text { is zero, namely } \\
\text { the random effect } \\
\text { is not significant }\end{array}$ & B-P test & $\begin{array}{l}\text { Prob > chibar2 }(01)=200.65 \\
\text { chibar2 }\end{array}$ & $\begin{array}{l}\text { Refuse original } \\
\text { assumption, and } \\
\text { select the } \\
\text { random effect }\end{array}$ \\
\hline $\begin{array}{l}\text { The random } \\
\text { effect model is } \\
\text { correct }\end{array}$ & $\begin{array}{l}\text { Hausman } \\
\text { test }\end{array}$ & chi2 (5)=-8.00 & $\begin{array}{l}\text { Refuse original } \\
\text { assumption, and } \\
\text { select the fixed } \\
\text { effect }\end{array}$ \\
\hline
\end{tabular}

\section{CONCLUSION}

Finally we decide to accept the result of the fixed effect model, namely with control variables considered, the financial service clustering has a significant push to the regional economic growth; meanwhile, governmental support, infrastructure and human capital have a significant push to the regional economic growth; yet the foreign investment resources have a significant inhibition against the economic growth, it is mainly due to the possibility of being low utilization of foreign capital and going against the healthy development of native economy especially the nongovernmental economic in the country.

\section{REFERENCES}

[1] Levine and Zervos, Stock Market, Banks and Economic Growth, American Economic Review, 1998 vol.82: 537-558.

[2] Beck Thorsten, Levine, Ross. Stock Markets, Banks and Growth: Panel Evidence, Journal of Banking and Finance, 2004: 423- 442.

[3] Chen, Development of Financial Intermediation and Economic Growth: The Chinese Experience, China Economic Review, 2006(17): 347-362.

[4] Apergis, Filippidis, Economidou. Financial Deepening and Economic Growth Linkages: A Panel Data Analysis, Review of world economics, 2007, vol.143: 179-198

[5] Zhou Li, Wang Ziming, Empirical Analysis of Financial Development and Economic Growth in Various Regions of China: 1978-2000[J]. Journal of Financial Research, 2002(10) :12-13.

[6] Liang Qi, Teng Jianzhou, Stock Market, Banks and Economic Growth: Empirical Analysis in China [J]. Journal of Financial Research, 2005(10):12-15.

[7] Yuan Xuchao, Analysis of Influence of Financial Development to Economic Growth in Chongqing [D]. 2008, master's thesis of Southwest University

[8] Luo Wenbo and Zhang Jiguo, Financial System Development, Financial Structure Deepening and Economic Growth-Co-integration Analysis on the Basis of Panel Data from 63 Country Samples [J]. Research on Economics and Management, 2010 (6): 32- 42.

[9] Liu Hong and Ye Yaoming, Financial Clustering and Regional Economic Growth: Research Overview [J] Inquiry into Economic Issues, 2007(11). 